\title{
SOME HISTORICAL REMARKS ON CONGENITAL SHORT PALATE
}

\author{
By HenRI P. J. WinTers
}

\author{
Plastic Surgical Unit, Surgical Department, Utrecht University Hospital
}

CongenitaL incompetence of the mechanism of velo-pharyngeal closure is nowadays a recognised clinical entity. Its most important manifestation is the open nasal speech. Investigation of the oral cavity and pharynx in cases of true congenital velo-pharyngeal incompetence reveals at first sight a completely normal palate with a perfect mobility of the velum, i.e., in articulation the soft palate is brought upwards and backwards in the normal way to the posterior pharyngeal wall. Only on closer scrutiny can one observe that the velum does not reach the posterior pharyngeal wall, due either to shortness of the soft palate or to an abnormally backward position of the posterior pharyngeal wall.

The incompetence of the valve mechanism can be proven by tests on nasal escape of air during speech or blowing with the aid of mirrors under the nares, and can even be measured to some extent with manometers connected to the nares. It can also directly be made visible by X-ray investigation during speech and blowing, either on photographs or with cinematography.

In a certain number of cases there are stigmata present, which make it probable that we are dealing with the ultimate result of an early disturbance in the embryonic development of the palate. Many authors have, from the first hazy days of recognition of this malformation, drawn much attention to several of these stigmata. As such should be mentioned the submucous clefts of the hard and the soft palate, the uvula bifida, the seemingly "gothic vault" of the palate and the already mentioned impression of an abnormally deep pharyngeal cavity.

In tracing back, to the very first publications on this subject, the written history of congenital velo-pharyngeal incompetence, it is remarkable that the earliest writers paid more attention to these secondary findings than to the primary cause of the patient's complaints. As we will see, they even went so far as to stipulate that the submucous cleft of the hard palate was the all-important malformation, leading to the velopharyngeal incompetence and the open nasal speech. To us, looking back into history with all the knowledge gathered until now, this attitude to the problem seems somewhat dark and incomprehensible.

This false approach becomes understandable when one considers the conviction of the surgeons of that era, that late spontaneous closure of palatal clefts was a frequent occurrence, without or after incomplete or unsuccessful surgical intervention (Billroth, I862; Passavant, I862; Langenbeck, 1864; Wolff, 1882). Although Langenbeck himself was clearly doubtful about the phenomenon and calls it " eine seltene Ausnahme von der Regel" (explaining the sometimes occurring spontaneous minimisation of clefts by cicatricial contracture), it seems reasonable to suppose that the medical profession at that time interpreted a submucous cleft of the hard palate as a sure sign of such a spontaneously healed cleft, be it only partly closed. Passavant (I865 a) declared himself an advocate of this theory.

It is, however, remarkable that even after Kelly in I910 shattered this then already wavering conviction by proving that congenital velo-pharyngeal incompetence could exist without submucous clefts of the palate, and moreover demonstrated that these submucous clefts could exist without a trace of open nasal speech, the standing communis opinio kept alive throughout the years. 
This was not the case with the bifid uvula. Already around 1865 some authorities (Langenbeck, I864; Passavant, I865a) stated that it was beyond doubt that the uvula had no relation to open nasal speech, although they still believed the bifid state to be a manifestation of an incompletely closed cleft palate.

The supposition that an abnormally deep pharynx is in some cases the cause of the velo-pharyngeal incompetence is a point of scientific interest to this day.

This bird's-eye view of the arena was necessary to set the stage for our voyage back into medical history in search of the very first written source of knowledge about the subject. It seems appropriate to pick up the thread of Ariadne in modern times and carefully to recede into the preceding century.

Where better could we start our expedition into the past than from the sound article by James Calnan in 1954 ? (Calnan, 1954 b). At the beginning of his paper he suggests that the characteristic syndrome of nasal speech without evident cleft of the palate is a rare condition, recognised for over Ioo years. Calnan gives the honour of the first discovery of the syndrome to P. J. Roux, and the calendar is set to I835. Let us now investigate this claim.

Calnan relates his historical location to a report in the Lancet, I835, I : 694-695, which he summarises as : "In I 835 P. J. Roux described the case of a young girl whose speech was so nasal as to be unintelligible : she had a cleft of the posterior portion of the soft palate, a notch in the posterior border of the hard palate palpable under intact mucosa."

Now, if we refer to the original report, we find that Roux reported " a vertical division of the soft palate to the extent of an inch, and reaching nearly to the uvula". There is no mention at all of a posterior notch in the hard palate. From Roux's story it is quite evident that he describes not a submucous cleft, but an aperture; a palatal fistula. This fact can be made still more convincing with the help of the reference made by Roux to an identical case treated by Dieffenbach. For in the book by Dieffenbach (I845), where dealing with this subject, there is certainly no mention at all of incompetence of non-cleft palates, but only of palatal fistulæ.

So we are on the wrong trail. But before we try to examine another way of approach we have to ask ourselves how Calnan came to put this report forward as the first milestone on the way to the understanding of congenital velo-pharyngeal incompetence. In his references Calnan cites another publication of Roux, dated I825. Clearly this book is the source that brought Dorrance, in his treatise on Congenital Insufficiency of the Palate, from 1930 to believe that: "Roux, in 1825 , first called the attention of the medical profession to congenital insufficiency of the palate. He stated in his paper that in I823 he was consulted by a young girl who nasalised so badly that her speech was unintelligible. He described in this girl a cleft of the posterior portion of the velum, and stated that there was faulty union of the osseous tissues of the hard palate under an intact mucosa."

However, in Roux's booklet (Roux, I825) we read on page 69: “. . . cas d'une jeune demoiselle que je vis au mois de juillet $1822, \ldots$. , chez laquelle la voûte palatine manquait seulement de parties solides depuis le bord postérieur jusque très-près de l'arcade alvéolaire, et transversalement dans l'étendue de son tiers moyen a-peu-près, en même temps que le voile du palais était divisé, mais dans la moitié seulement de sa hauteur." From this citation it is clear that Roux, as far as we know, has indeed been the first author to describe a submucous cleft of the hard palate. But it is also clear that he mentioned it as a remarkable extension of a cleft velum, and NOT as a case of velo-pharyngeal incompetence. For the discrepancy in the years of the consultation, as mentioned by Roux, respectively cited by Dorrance, I have no explanation. Evidently speaking about the same girl patient again on page 84 , Roux states too: 
". . . et en éprouvaient à un haut degré toutes les incommodités." This may signify Dorrance's comment on the girl's speech qualities, but in my opinion does not say so.

Calnan $(1954 b)$ provides us with another source for investigation when he writes that : " in I846 Demarquay described a similar case. No treatment was recommended, and indeed under the conditions then pertaining in surgery this was understandable."

The name of Demarquay is also mentioned by Dorrance (1930), who states: "Demarquay, in 1846, exhibited a dissection (author's italics) in which there was a cleft of the velum and the bony palate, the cleft in the latter being filled with fibrous tissue ; the mucosa was intact." It is remarkable that Calnan mentions that no treatment was recommended, and Dorrance refers to a dissection. And now to the original publication.

Bulletin Number I of the "Société Anatomique de Paris," January I846, pages II-I2, states that Mons. Demarquay demonstrated an autopsy finding in which the palate showed absence of palatal muscles in the midline of the velum, and non-union in the midline at the last part of the hard palate, that defect being filled with fibrous tissue. He did not mention whether this anatomical abnormality had caused complaints of open nasal speech to its possessor while still alive, and neither if the mucosa was intact.

So here again our investigation goes astray. Only one point looks probable: Demarquay was the first to point to the existence of the phenomenon of the submucous cleft of the hard and soft palate. This important historical probability may explain the error of Calnan and Dorrance as we will see later on in our search for the historical truth.

In eliminating Roux and Demarquay as candidates in our inquest, we have to look for other landmarks in our chronological journey. Let us go back into time a little further and explore the paper by Kelly in I910.

After giving a satisfactory description of the congenital velo-pharyngeal incompetence, Kelly gives Lermoyez the credit of having published in I 892 an excellent monograph, in which, for the first time, the subject was dealt with lucidly and in detail. So let us bring Lermoyez into the witness box.

Lermoyez (1892) formulates as his definition that "L'insuffisance vélo-palatine" is a congenital anomaly, through developmental disturbance, in which the velum appears healthy, mobile and of normal shape, but is relatively too short to close the naso-pharyngeal aperture. He also states his conviction that the anomaly is always associated with a submucous cleft of the posterior part of the hard palate and with a bifid uvula of varying extent. This conviction of an absolute correlation between congenital velo-pharyngeal insufficiency and a submucous cleft of the hard palate we will find with all earlier writers on the subject until Kelly in I9Io proves it to be a fallacy, although we have to give Gutzmann (1899) the honour of expressing his doubts on this matter already much earlier.

All the same this fallacy was the reason why all investigators of the past century were content with the finding of open nasal speech, associated with a normal appearance of the palate and a submucous cleft of the hard palate, to diagnose a congenital velopharyngeal insufficiency. It now seems clear why Lermoyez also gives Roux and Demarquay the credit of being the first authors on the anomaly; falsely, as we hope to have proved above.

When studying other papers on the subject (Gutzmann, I899; Seemann, 1924) one gets the impression that they rely on the authority of Lermoyez in the matter of pedigree. As probably did Kelly, Dorrance and Calnan. So it is a normal line of pursuit to search the case reports assembled by Lermoyez (1892). He sums up three cases published by Passavant. Study of the original articles reveals that Passavant 
(1862, I865 a) mentioned only two patients: a little girl and a grown-up man. The error of Lermoyez certainly derives from the fact that Passavant mentions the girl patient in both reports at the respective ages.

Passavant reported this girl patient for the first time in I862. She had a cleft lip and a spontaneously healed small cleft in the soft palate. At the time of Passavant's later examination (I865) the velum was closed; there was a broad and deep submucous cleft of the hard palate and an open nasal speech. She visibly could not bring the velum into contact with the posterior pharyngeal wall.

The man was reported in I865 (Passavant, I865a). He had a submucous cleft of the hard palate, an intact velum, a small bifid uvula and a heavy open nasal speech. His sister had a palatal cleft.

These cases are convincing descriptions of congenital velo-pharyngeal incompetence, with the stage set for 1862 as regards the first report. That Passavant has, for his era, a genuine insight into the true physiological background of the phenomenon, can be deduced also from his use of the term "Insufficienz" in open nasal speech after surgical closure of clefts in the soft palate (Passavant, $1865 b$ ).

The case reports from Trélat (I867, I869), Notta (I869), Ehrmann (I880), Wolff (I882) and Kayser (I89I) refer also to genuine congenital velopharyngeal incompetences. They are, however, of no importance in this argument because of their later dates.

It seems that at last we have found the survivor of our eliminating investigation. Unfortunately not : there is still another claim to be examined.

In I864, the great German surgeon von Langenbeck, when discussing palatal clefts, called

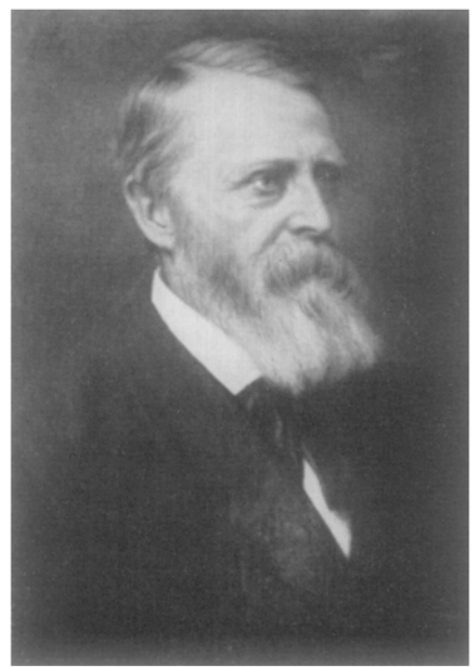

Dr Ph. Gustav Passavant, 1815-1893. (By courtesy of the Director of the Bürgerhospital, Frankfurt-am-Main.) attention to his observation that sometimes one encountered individuals without any palatal defect, but with an open nasal speech. On the edge of discovery, however, Langenbeck contented himself with the assumption that these patients were the victims of close contact with relatives or friends who had an open nasal speech, be it from cleft palates or other causes. So he declares the open nasal speech in these cases to be an imitational, psychological phenomenon. In his extensive paper (1862) he does not mention submucous clefts, nor indeed insufficient but intact palates.

It is particularly impressive that Passavant (I865 $b$ ), commenting on the assumption by Langenbeck of an imitational origin, shows himself to be unconvinced, and states that it seems more logical to assume a congenital shortness of the palate. Here Passavant refers to the (already mentioned) similar case of the brother of a girl patient with a cleft palate. Of course Passavant relied on the standing theory of a "Naturheilung" in a cleft palate case, but definitely rejected the Langenbeck suggestion of an open nasal speech from imitational origin.

All the witnesses have been heard, the facts have been examined to our satisfaction, and we are now justified in proclaiming Gustav Passavant the successful claimant in this medico-historical trial. This is the more gratifying because of the enormous stimulus Gustav Passavant has given to the investigation and understanding of velar function.

May this paper restore Gustav Passavant to his rightful place again after James 
Calnan's most just and fair criticism of the phenomenon known as "Passavant's Ridge", as put forward in 1954 under the title "The Error of Gustav Passavant" (Calnan, I954a).

\section{REFERENCES}

Billroth, Th. (1862). Arch. klin. Chir., I I, 658.

Calnan, J. (I954 a). Plast. reconstr. Surg., I3, 275.

- (1954 b). Brit. F. plast. Surg., 6, 264.

Demarquay (1846). Bull. Soc. Anat. Paris, r, i I.

DiefFenbach, J. F. (1845). "Die Operative Chirurgie." Leipzig: F. A. Brockhaus.

Dorrance, G. M. (1930). Arch. Surg., 21, 185.

EHRMANN (1880). Gaz. med. Strasbourg, ro, i 18.

GutZMANN, H. (1899). Berl. klin. Wschr., 36, 809.

KAYSER, R. (1891). Dtsch. med. Wschr., 26, 824.

KELLY, A. B. (I910). F. Laryng., 25, 6, 2 I.

LANGENBECK, B. vON (1862). Arch. klin. Chir., 2, 205.

- (1864). Arch. klin. Chir., 5, I.

Lermoyez, M. (1892). Ann. Mal. Oreil. Larynx, 18, 3, I6 I.

NotTa (1869). Bull. Soc. Chir., In, 4I2.

Passavant, G. (1862). Arch. Heilk., 3, 305.

- (1865 a). Arch. klin. Chir., 6, 333 .

(1865 b). Arch. klin. Chir., 6, 586 .

Roux, P. J. (1825). “Mémoires sur Staphylorrhaphie." Paris : J.-S. Chaudé. (I835). Lancet, $x, 694$.

SeEmann, M. (1924). Arch. int. Laryng., 30, 388.

Trélat, U. (I867). Bull. Soc. Chir., 8, 450.

- (1869). Bull. Soc. Chir., ro, 402.

WOL.FF, J. (1882). Berl. klin. Wschr., 38, 582 .

Submitted for publication, November 1965. 